\title{
Stable hepatitis C virus RNA detection by RT-PCR during four days
} storage

\author{
Anne-Isabelle de Moreau de Gerbehaye ${ }^{1}$, Monique Bodéus ${ }^{1}$, Annie Robert ${ }^{2}$, \\ Yves Horsmans ${ }^{3}$ and Patrick Goubau*1
}

Address: ${ }^{1}$ Department of Virology, Université Catholique de Louvain et Cliniques Universitaires Saint-Luc, Brussels, Belgium, ${ }^{2}$ Department of Epidemiology, Université Catholique de Louvain et Cliniques Universitaires Saint-Luc, Brussels, Belgium and ${ }^{3}$ Department of Gastro-enterology, Université Catholique de Louvain et Cliniques Universitaires Saint-Luc, Brussels, Belgium

E-mail: Anne-Isabelle de Moreau de Gerbehaye -ng.deradigues@yucom.be; Monique Bodéus - bodeus@mblg.ucl.ac.be; Annie Robert - annie.robert@epid.ucl.ac.be; Yves Horsmans - horsmans@gaen.ucl.ac.be; Patrick Goubau* - goubau@mblg.ucl.ac.be *Corresponding author

Published: 4 October 2002

BMC Infectious Diseases 2002, 2:22
Received: 16 January 2002

Accepted: 4 October 2002

This article is available from: http://www.biomedcentral.com/I47I-2334/2/22

(C) 2002 de Moreau de Gerbehaye et al; licensee BioMed Central Ltd. This article is published in Open Access: verbatim copying and redistribution of this article are permitted in all media for any purpose, provided this notice is preserved along with the article's original URL.

\begin{abstract}
Background: Suboptimal specimen processing and storage conditions of samples which contain hepatitis $\mathrm{C}$ virus (HCV) RNA may result in a decline of HCV RNA concentration or false-negative results in the detection of HCV RNA in serum. We evaluated the stability of HCV RNA in serum and clotted blood samples stored at room temperature or at $4^{\circ} \mathrm{C}$ for 4 days with the aim of optimizing the standard procedures of processing and storage of samples.

Methods: Blood from five HCV RNA positive patients was collected in tubes with and without separator gel, centrifuged I or 6 hours after collection. Samples were then left 6, 24, 48, 72 or 96 $h$ at room temperature $\left(21.5-25.4^{\circ} \mathrm{C}\right)$ or at $4^{\circ} \mathrm{C}$ before determining their HCV RNA level using the COBAS AMPLICOR HCV MONITOR Test, vs 2.0 (Roche Diagnostic Systems).

Results: The logarithm of the HCV RNA level measurements remained within a 0.3 value of the means for 4 days at both temperatures (room temperature or $4^{\circ} \mathrm{C}$ ).

Conclusions: We conclude that blood samples may be collected and aliquoted within $6 \mathrm{~h}$ of collection and can be stored at $4^{\circ} \mathrm{C}$ for 72 hours as proposed by the manufacturer without significant differences in measured HCV RNA level. Our results indicate that lapses in this scheme may still yield reliable results.
\end{abstract}

\section{Background}

Both hepatitis C virus (HCV) RNA viral load and HCV genotype have been described as important for predicting the response to anti-HCV therapy. Quantification of HCV RNA in serum is used to predict treatment response and to monitor antiviral therapy. Suboptimal specimen processing and storage conditions among other factors (e.g. operator problems, reagent lot variability, etc.) may cause false-negative results in HCV RNA detection or underestimate HCV RNA load values. Since serum specimens are often transported to central laboratories for HCV RNA level determination, it was important to define conditions that preserve HCV RNA integrity. The aim of this study was to evaluate the stability of HCV RNA in serum and in clotted blood at room temperature and at $4^{\circ} \mathrm{C}$ for 4 days 
Table I: Serum tube handling before testing

\begin{tabular}{|c|c|c|c|c|c|}
\hline $\begin{array}{l}\text { Tube I without } \\
\text { separator }=>\end{array}$ & $\begin{array}{l}\text { centrifuge within } \\
\text { I hour => }\end{array}$ & I aliquot (time 0 ) at $-80^{\circ} \mathrm{C}=>$ & tube kept at $4^{\circ} \mathrm{C}=>$ & aliquots at $-80^{\circ} \mathrm{C}$ & $\begin{array}{l}\text { at } 6 \text { hours } \\
\text { at } 24 \text { hours } \\
\text { at } 48 \text { hours } \\
\text { at } 72 \text { hours } \\
\text { at } 96 \text { hours }\end{array}$ \\
\hline $\begin{array}{l}\text { Tube } 2 \text { without } \\
\text { separator }=>\end{array}$ & $\begin{array}{l}\text { centrifuge within } \\
\text { I hour }=>\end{array}$ & & tube kept at room $t^{\circ}=>$ & aliquots at $-80^{\circ} \mathrm{C}$ & $\begin{array}{l}\text { at } 6 \text { hours } \\
\text { at } 24 \text { hours } \\
\text { at } 48 \text { hours } \\
\text { at } 72 \text { hours } \\
\text { at } 96 \text { hours }\end{array}$ \\
\hline $\begin{array}{l}\text { Tube } 3 \text { with } \\
\text { separator }=>\end{array}$ & $\begin{array}{l}\text { centrifuge within } \\
\text { I hour }=>\end{array}$ & $\begin{array}{l}\text { make } 6 \text { aliquots and keep one } \\
\text { (time } 0 \text { ) } \\
\text { at }-80^{\circ} \mathrm{C}=>\end{array}$ & aliquots kept at $4^{\circ} \mathrm{C}=>$ & aliquots at $-80^{\circ} \mathrm{C}$ & $\begin{array}{l}\text { at } 6 \text { hours } \\
\text { at } 24 \text { hours } \\
\text { at } 48 \text { hours } \\
\text { at } 72 \text { hours } \\
\text { at } 96 \text { hours }\end{array}$ \\
\hline $\begin{array}{l}\text { Tube } 4 \text { with } \\
\text { separator }=>\end{array}$ & $\begin{array}{l}\text { centrifuge within } \\
\text { I hour => }\end{array}$ & make 5 aliquots $=>$ & aliquots at room $t^{\circ}=>$ & aliquots at $-80^{\circ} \mathrm{C}$ & $\begin{array}{l}\text { at } 6 \text { hours } \\
\text { at } 24 \text { hours } \\
\text { at } 48 \text { hours } \\
\text { at } 72 \text { hours } \\
\text { at } 96 \text { hours }\end{array}$ \\
\hline $\begin{array}{l}\text { Tube } 5 \text { with } \\
\text { separator }=>\end{array}$ & $\begin{array}{l}\text { at room } t^{\circ} \text { for } 6 \text { hours } \\
\text { then centrifuged }=>\end{array}$ & $\begin{array}{l}\text { make } 9 \text { aliquots and } \\
\text { keep I aliquot }(6 \mathrm{~h}) \text { at }-80^{\circ} \mathrm{C}=>\end{array}$ & 4 aliquots at $4^{\circ} \mathrm{C}=>$ & aliquots at $-80^{\circ} \mathrm{C}$ & $\begin{array}{l}\text { at } 24 \text { hours } \\
\text { at } 48 \text { hours } \\
\text { at } 72 \text { hours } \\
\text { at } 96 \text { hours }\end{array}$ \\
\hline & & & 4 aliquots at room $t^{\circ}$ & aliquots at $-80^{\circ} \mathrm{C}$ & $\begin{array}{l}\text { at } 24 \text { hours } \\
\text { at } 48 \text { hours } \\
\text { at } 72 \text { hours } \\
\text { at } 96 \text { hours }\end{array}$ \\
\hline
\end{tabular}

in order to optimize the standard procedures of processing and storage.

\section{Methods}

We collected blood by venipuncture from five HCV RNA positive patients ( 2 female and 3 male; ages from 40 to 67 years) at time 0 after informed consent. All sampling and testing were done in accordance with ethical standards in Belgium and according to the guidelines of the 1975 Declaration of Helsinki. From each patient, three blood samples were collected in $7 \mathrm{ml}$-tubes with separator and two blood samples in $7 \mathrm{ml}$-tubes without separator (Sarstedt, Nombrecht, Germany). The tubes with separator contain a gel barrier to enable immediate separation of serum from the clot following a single centrifugation step (during 10 minutes at $3000 \mathrm{rpm}$ ). Two tubes with separator and the two tubes without separator were centrifuged at $3000 \mathrm{rpm}$ during 10 minutes within the hour of collection (Table 1).

One aliquot $(170 \mu \mathrm{l})$ of the serum from the tubes without separator was transfered in a microtube as reference for titre determination at time-point 0 and immediately frozen at $-80^{\circ} \mathrm{C}$ until testing. After centrifugation, one tube without separator was kept at $4^{\circ} \mathrm{C}$ and the other tube without separator at room temperature during 6, 24, 48, 72 and 96 hours before freezing an aliquot at $-80^{\circ} \mathrm{C}$. This procedure allowed contact between serum and clot over these respective times. Room temperature was checked with a digital maximum/minimum thermometer and found to be between $21.5^{\circ} \mathrm{C}$ and $25.4^{\circ} \mathrm{C}$ over the study period.

After this centrifugation, the serum of two tubes with separator was aliquoted in 11 dry microtubes (170 $\mu \mathrm{l}$ each). One microtube was used as a reference for titre determination at time-point 0 (reference) and was immediately stored at $-80^{\circ} \mathrm{C}$ until testing. Five dry microtubes were stored at $4^{\circ} \mathrm{C}$ and five dry microtubes were stored at room temperature during $6,24,48,72$ and 96 hours respectively before being frozen at $-80^{\circ} \mathrm{C}$.

The third tube with separator was kept at room temperature $\left(21.5^{\circ} \mathrm{C}-25.4^{\circ} \mathrm{C}\right)$ during 6 hours before being centrifuged at $3000 \mathrm{rpm}$ during 10 minutes and the serum was aliquoted ( $170 \mu \mathrm{l} \mathrm{each})$ in 9 dry microtubes. One microtube was used as reference for titre determination at 6 hours and was stored at $-80^{\circ} \mathrm{C}$ until testing. The 8 other microtubes were kept during 24, 48, 72 and 96 hours before being frozen at $-80^{\circ} \mathrm{C}: 4$ microtubes at $4{ }^{\circ} \mathrm{C}$ and $4 \mathrm{mi}$ crotubes at room temperature. On the serum of each 


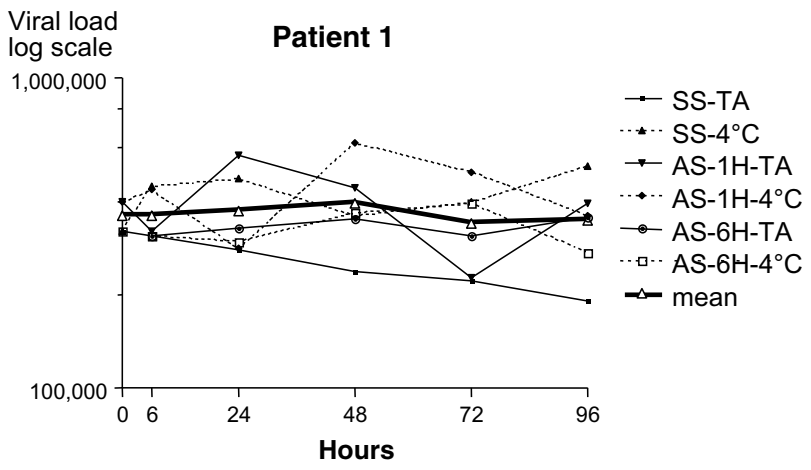

Figure I

Viral load measurements over time in patient $\mathrm{I}$ in $\mathrm{IU} / \mathrm{ml}$ on a log scale. SS-TA: tube without serum separator at room temperature; SS- $4^{\circ} \mathrm{C}$ : tube with serum separator at $4^{\circ} \mathrm{C}$; AS- IHTA: tube with separator, centrifuged within the first hour and kept at room temperature; $\mathrm{AS}-\mathrm{IH}-4^{\circ} \mathrm{C}$ : tube with separator, centrifuged within the first hour and kept at $4^{\circ} \mathrm{C}$; AS-6H-TA: tube with separator, centrifuged after 6 hours and kept at room temperature; AS- $6 \mathrm{H}-4^{\circ} \mathrm{C}$ : tube with separator, centrifuged after 6 hours and kept at $4^{\circ} \mathrm{C}$. The mean of measurements at each point of time is given in open triangles linked by a thick line.

reference microtube, a qualitative nested RT-PCR was performed to confirm the presence of HCV RNA in each sample. After this confirmation, a quantitative RT-PCR was performed to determine the HCV RNA load, using an automated commercial method: COBAS AMPLICOR HCV MONITOR Test, version 2.0 (Roche Diagnostic Systems Inc., Branchburg, NJ, USA). This quantitative RT-PCR was also performed on each microtube frozen at $-80^{\circ} \mathrm{C}$. All the reference samples (at time-point 0 ) were positive for the qualitative nested RT-PCR and the quantitative RT-PCR in the 5 patients included in this study. To minimize the effect of analytical variability all samples from the same patient were tested in the same analytical series. A high and a low positive control were tested in each test run. RNA extraction and RT-PCR were performed according to the manufacturer's instructions. The results are expressed in international units (IU) per milliliter. Statistical analysis and data transformations (log transformation, SD and SE, comparison of means, confidence intervals, coefficient of variation, percentile distribution) were performed with the PRISM Software Version 2.0 (GraphPad, San Diego, CA, USA). A difference was considered significant if the pvalue was lower than 0.05 .

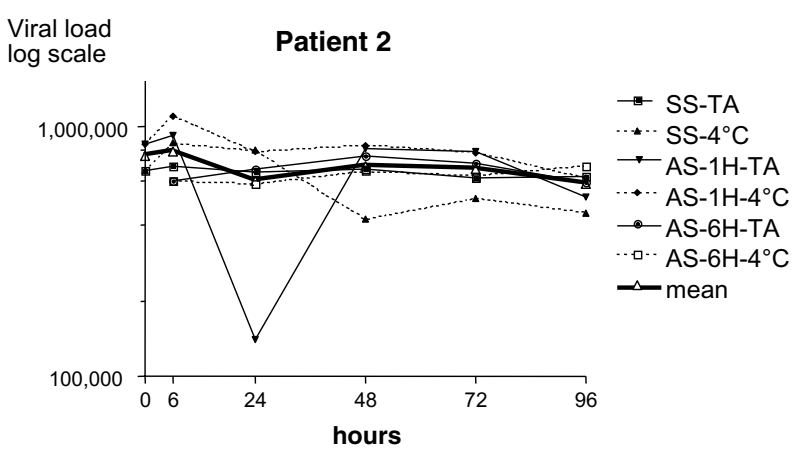

Figure 2

Viral load measurements over time in patient 2 in $\mathrm{IU} / \mathrm{ml}$ on a log scale. SS-TA: tube without serum separator at room temperature; $\mathrm{SS}-4^{\circ} \mathrm{C}$ : tube with serum separator at $4^{\circ} \mathrm{C}$; $\mathrm{AS}-\mathrm{IH}$ TA: tube with separator, centrifuged within the first hour and kept at room temperature; $\mathrm{AS}-\mathrm{IH}-4^{\circ} \mathrm{C}$ : tube with separator, centrifuged within the first hour and kept at $4^{\circ} \mathrm{C}$; AS-6H-TA: tube with separator, centrifuged after 6 hours and kept at room temperature; AS- $6 \mathrm{H}-4^{\circ} \mathrm{C}$ : tube with separator, centrifuged after 6 hours and kept at $4^{\circ} \mathrm{C}$. The mean of measurements at each point of time is given in open triangles linked by a thick line.

\section{Results}

All the samples stored at room temperature or stored at $4^{\circ} \mathrm{C}$ for $6,24,48,72$, and 96 hours were positive for the quantitative RT-PCR. The mean viral load was 362,000 $\mathrm{IU} / \mathrm{ml}(5.544 \mathrm{log} ; \mathrm{SD}=0.023)$ for patient $1 ; 680,940 \mathrm{IU} /$ $\mathrm{ml}(5.818 \log ; \mathrm{SD}=0.063)$ for patient $2 ; 73,690 \mathrm{IU} / \mathrm{ml}$ (4.862 log; $\mathrm{SD}=0.028)$ for patient $3 ; 134,630 \mathrm{IU}: \mathrm{ml}$ $(5.119 \mathrm{log} ; \mathrm{SD}=0.097)$ for patient 4 and $981,870 \mathrm{ml}$ ( $5.977 \mathrm{log}$; $\mathrm{SD}=0.034$ ) for patient 5 . All the values of the positive controls in each of the 10 analytical series were between the expected lower and the upper limits. The mean viral load for the high positive control was 74,900 $\mathrm{IU} / \mathrm{ml}(4.87 \log ; \mathrm{SD}=0.064)$ with an interrun coefficient of variation $(\mathrm{CV})$ of $14.9 \%$. For the low positive control, the mean was $5,838 \mathrm{IU} / \mathrm{ml}(3.751 \mathrm{log}$; $\mathrm{SD}=\mathrm{O} .122)$ with an interrun CV of $27.3 \%$. Figures 1 to 5 show, for each patient, the values of viral load measurements in $\mathrm{IU} / \mathrm{ml}$ on the different samples at each time point on a logarithmic scale. Mean values of measurements are given with a thick line. Mean values did not change much over time. The CV of measurements on different samples in a same patient at different time points varied between $0.16 \%$ and $27.9 \%$ at time $0,19.2 \%$ and $27.5 \%$ at 6 hours, $13.7 \%$ and $40.0 \%$ at 24 hours, $7 \%$ and $33.3 \%$ at 48 hours, $16.1 \%$ and $32.3 \%$ at 72 hours and $12.2 \%$ and $33.4 \%$ at 96 hours. The logarithm of the viral load measurements on each sample re- 


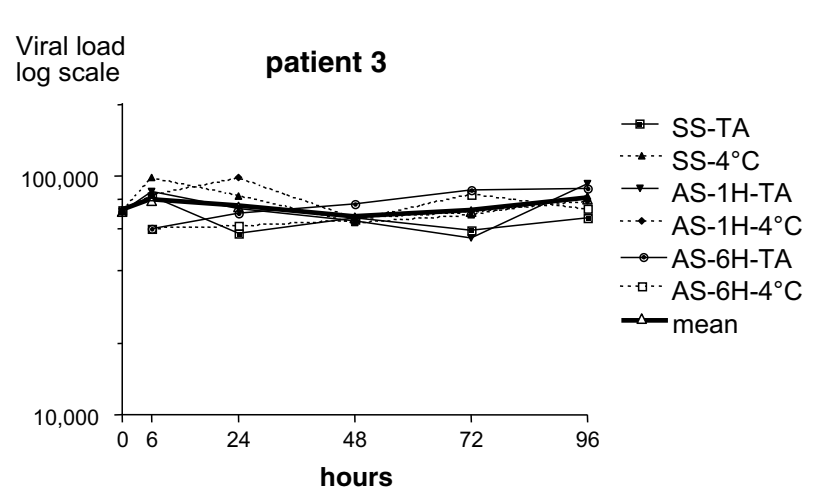

Figure 3

Viral load measurements over time in patient 3 in $\mathrm{IU} / \mathrm{ml}$ on a log scale. SS-TA: tube without serum separator at room temperature; SS- $4^{\circ} \mathrm{C}$ : tube with serum separator at $4^{\circ} \mathrm{C}$; AS- IHTA: tube with separator, centrifuged within the first hour and kept at room temperature; $\mathrm{AS}-\mathrm{IH}-4^{\circ} \mathrm{C}$ : tube with separator, centrifuged within the first hour and kept at $4^{\circ} \mathrm{C}$; AS-6H-TA: tube with separator, centrifuged after 6 hours and kept at room temperature; AS- $6 \mathrm{H}-4^{\circ} \mathrm{C}$ : tube with separator, centrifuged after 6 hours and kept at $4^{\circ} \mathrm{C}$. The mean of measurements at each point of time is given in open triangles linked by a thick line.

mained at any time within 0.3 of the mean. No significant difference was observed for any single patient between the viral load obtained from different kinds of tubes (with or without separator), after different times of centrifugation and separation ( 1 hour or 6 hours after collection) or with different storage conditions (at room temperature or refrigerated at $4^{\circ} \mathrm{C}$ ) for variable periods of time.

\section{Discussion}

Both hepatitis C virus (HCV) RNA viral load and HCV genotype have been described as important for predicting the response to anti-HCV therapy. Suboptimal storage temperatures may affect HCV RNA stability and influence viral load measurements.

There was one outlier value in patient 2 after 24 hours of storage at room temperature (tube with separator, whose serum was separated from erythrocytes within 1 hour post-collection). This isolated discordance was not found with the other samples of the same patient at any other time point. This discordant value certainly points to an analytical error. It explains a higher CV at 24 hours. In the literature there are still controversies regarding the stability of HCV RNA under different processing and storage conditions. Several studies have shown that HCV RNA is

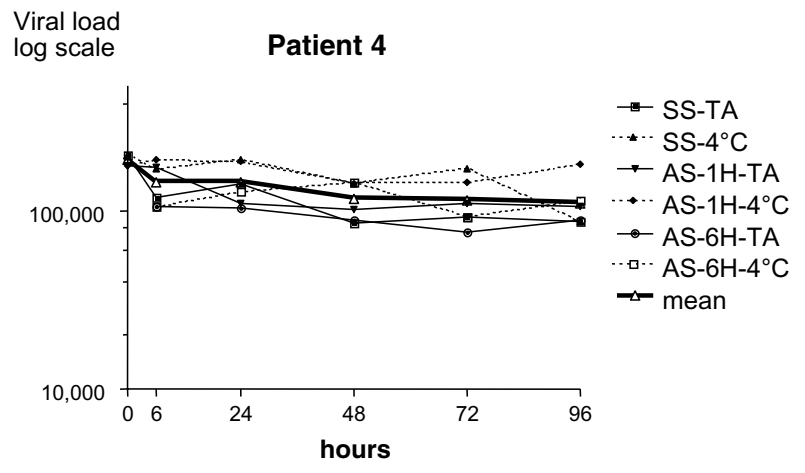

Figure 4

Viral load measurements over time in patient 4 in $\mathrm{IU} / \mathrm{ml}$ on a log scale. SS-TA: tube without serum separator at room temperature; SS- $4^{\circ} \mathrm{C}$ : tube with serum separator at $4^{\circ} \mathrm{C}$; AS- IHTA: tube with separator, centrifuged within the first hour and kept at room temperature; $\mathrm{AS}-\mathrm{IH}-4^{\circ} \mathrm{C}$ : tube with separator, centrifuged within the first hour and kept at $4^{\circ} \mathrm{C}$; AS-6H-TA: tube with separator, centrifuged after 6 hours and kept at room temperature; AS- $6 \mathrm{H}-4^{\circ} \mathrm{C}$ : tube with separator, centrifuged after 6 hours and kept at $4^{\circ} \mathrm{C}$. The mean of measurements at each point of time is given in open triangles linked by a thick line.

unstable in serum after storage at room temperature [13]. Some reports have claimed that HCV RNA in separated serum is stable for at least 4 days at $4{ }^{\circ} \mathrm{C}$ but that concentrations decrease with increasing temperature [5] or that RNA is stable for at least 3 days at both room temperature and $4^{\circ} \mathrm{C}[6]$. Other reports showed that the concentration of HCV RNA remained stable in serum specimens subjected to three to eight freeze-thaw cycles $[7,8]$. Results may differ according to type of collection tube. Wang et al. reported already 10 years ago that serum or citrated plasma specimens are satisfactory for detecting HCV RNA by PCR, but that heparinized blood specimens are not [9]. Miskowsky et al.[10] and Damen et al.[11] demonstrated that plasma tubes (EDTA or ACD) or serotubes are suitable to measure HCV RNA concentrations. For Grant et al.[12] whole blood anticoagulated with EDTA or CPDA-1/EDTA may be stored at up to $25^{\circ} \mathrm{C}$ for 5 days without any significant loss in plasma HCV RNA level. Kessler et al. concluded that HCV RNA remains stable in NASTs (tubes which contain a liquid nucleic acid stabilizer) at room temperature for at least $96 \mathrm{~h}$, whereas a significant increase of HCV RNA was observed in two different types of EDTA tubes [13].

These different studies use different blood collection tubes and different processing times and are therefore not 


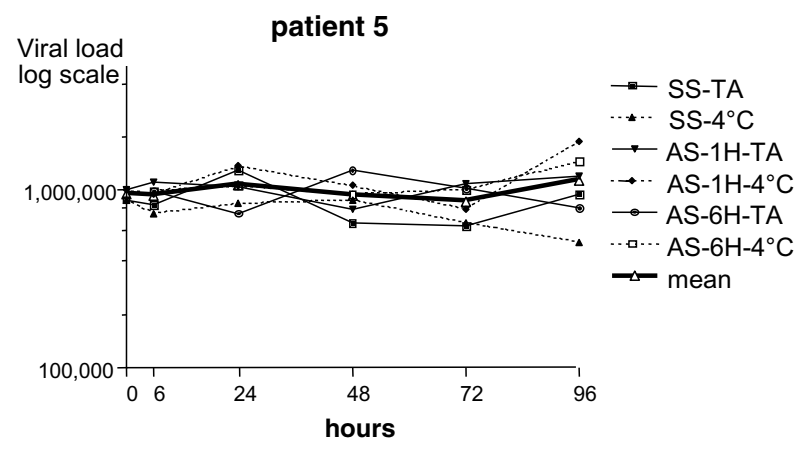

Figure 5

Viral load measurements over time in patient $5 \mathrm{in} \mathrm{IU} / \mathrm{ml}$ on a log scale. SS-TA: tube without serum separator at room temperature; SS- $4^{\circ} \mathrm{C}$ : tube with serum separator at $4^{\circ} \mathrm{C}$; AS- IHTA: tube with separator, centrifuged within the first hour and kept at room temperature; $\mathrm{AS}-\mathrm{IH}-4^{\circ} \mathrm{C}$ : tube with separator, centrifuged within the first hour and kept at $4^{\circ} \mathrm{C}$; AS- $6 \mathrm{H}-\mathrm{TA}$ : tube with separator, centrifuged after 6 hours and kept at room temperature; $\mathrm{AS}-6 \mathrm{H}-4^{\circ} \mathrm{C}$ : tube with separator, centrifuged after 6 hours and kept at $4^{\circ} \mathrm{C}$. The mean of measurements at each point of time is given in open triangles linked by a thick line.

really comparable. The general picture is that HCV viral RNA is more stable than generally thought before. In our laboratory we used to accept only serum, which had been centrifuged and separated within $1 \mathrm{~h}$ of collection, frozen at $-70^{\circ} \mathrm{C}$ to $-80^{\circ} \mathrm{C}$ if stored and transported frozen to our laboratory for the measurement of HCV RNA. To allow less strict procedures we evaluated the effects on the HCV RNA stability of two types of blood collection tubes (dry tubes with separator and without separator), three processing times (centrifugation within $1 \mathrm{~h}$ after collection without separation of serum from the clot, centrifugation within $1 \mathrm{~h}$ followed by separation and centrifugation $6 \mathrm{~h}$ later), two storage temperatures (at $+4^{\circ} \mathrm{C}$ and at room temperature) and five storage times ( 6 , $24,48,72$ and $96 \mathrm{~h}$ ). We chose to compare only serum specimens because in different reports only slight differences are found between serum and plasma. Moreover serum samples are usually used for other viral serological parameters. The two temperatures analysed in our study are the most frequent storage and transport temperatures for blood samples. We compared the HCV RNA levels during 4 days of storage because it is a common duration to which we are confronted with samples coming from other centres. No significant differences were observed in any patient between the viral loads from different kinds of se- rum tubes, with different processing and storage conditions. This relatively long stability of HCV RNA may be explained by the particulate nature of this RNA, i.e. the fact that it is essentially enclosed in viral particles.

Our results validate the procedure proposed by the manufacturer, i.e. that blood samples must be collected and aliquoted within $6 \mathrm{~h}$ of collection and may be stored at $4^{\circ} \mathrm{C}$ for as long as 72 hours. Furthermore our results indicate that lapses in this scheme may still yield correct results.

\section{Competing interests}

We have no financial links or arrangements with the manufacturer of HCV RNA kits, Roche Diagnostics.

\section{Acknowledgements}

We thank the technical assistance of Mr Luc Croonen and Mrs Arlette Despineux. This work was supported in part by grant $n^{\circ} 3.4523 .98 \mathrm{~F}$ of the Belgian 'Fond de la Recherche Scientifique Medicale'.

\section{References}

I. Cuypers HT, Bresters D, Winkell N, et al: Storage conditions of blood and primer selection affect the yield of cDNA polymerase chain reaction products of hepatitis C virus. J Clin Microbiol 1992, 30:3220-3224

2. Busch MP, Wilber JC, Johnson P, Tobler L, Evans CS: Impact of specimen handling and storage on detection of hepatitis $\mathrm{C}$ virus RNA. Transfusion 1992, 32:420-425

3. Halfon P, Khiri H, Gerolami V, et al: Impact of various handling and storage conditions on quantitative detection of hepatitis C virus RNA. I Hepatol 1996, 25:307-3I I

4. Gessoni G, Barin P, Frigato A, et al: The stability of hepatitis C virus RNA after storage at $+4^{\circ} \mathbf{C}$. J Viral Hepat 2000, 7:283-286

5. Krajden M, Minor JM, Zhao J, Rifkin O, Comanor L: Assessment of hepatitis $C$ virus RNA stability in serum by the Quantiplex branched DNA assay. I Clin Virol 1999, 14:137-143

6. Trabaud MA, Bailly F, Colucci G, Trepo C: Stability of hepatitis C virus RNA in serum from samples collected in a closed-tube system for serum separation and transport, as measured bya quantitative competitive PCR assay. J Viral Hepat 1996, 3:207209

7. Davis GL, Lau JY, Urdea MS, et al: Quantitative detection of hepatitis C virus RNA with a solid-phase signal amplification method: definition of optimal conditions for specimen collection and clinical application in interferon-treated patients. Hepatology 1994, 19:1337-1341

8. Krajden M, Minor JM, Rifkin O, Comanor L: Effect of multiple freeze-thaw cycles on hepatitis B virus DNA and hepatitis C virus RNA quantification as measured with branched-DNA technology. I Clin Microbiol 1999, 37: 1683-1686

9. Wang JT, Wang TH, Sheu JC, Lin SM, Lin JT, Chen OS: Effects of anticoagulants and storage of blood samples on efficacy of the polymerase chain reaction assay for hepatitis $\mathbf{C}$ virus. J Clin Microbiol 1992, 30:750-753

10. Miskovsky EP, Carrella AV, Gutekunst K, Sun CA, Quinn TC, Thomas DL: Clinical characterization of a competitive PCR assay for quantitative testing of hepatitis C virus. J Clin Microbiol 1996, 34:1975-1979

II. Damen M, Sillekens P, Sjerps M, et al: Stability of hepatitis C virus RNA during specimen handling and storage prior to NASBA amplification. J Virol Methods 1998, 72: 175-184

12. Grant PR, Kitchen A, Barbara JA, et al: Effect of handling and storage of blood on the stability of hepatitis C virus RNA : implications for NA T testing in transfusion practice. Vox Sang 2000, 78: $137-142$

13. Kessler HH, Stelzl E, Raggam RB, et al: Effects of storage and type of blood collection tubes on hepatitis $C$ virus level in whole blood samples. J Clin Microbiol 200 I, 39: I788-1790 


\section{Pre-publication history}

The pre-publication history for this paper can be accessed here:

http://www.biomedcentral.com/1471-2334/2/22/prepub

Publish with BioMed Central and every scientist can read your work free of charge

"BioMedcentral will be the most significant development for disseminating the results of biomedical research in our lifetime."

Paul Nurse, Director-General, Imperial Cancer Research Fund

Publish with BMC and your research papers will be:

- available free of charge to the entire biomedical community

- peer reviewed and published immediately upon acceptance

- cited in PubMed and archived on PubMed Central

- yours - you keep the copyright
BioMedcentral.com editorial@biomedcentral.com 